\title{
ガス絶縁変圧器の異常診断のための分解ガスの研究
}

正員岡部成炎 (東京䉓力)
正員小林恒夫 (東芝)
正員石岡康昭 (東芝)
正員士由繁之 (東芝)

\begin{tabular}{|c|c|c|}
\hline 正員 & 大野家公 & （東京電力） \\
\hline 正 & 川口監二 & （東芝 \\
\hline 正 & 茾上 保 & （東 芝 \\
\hline 正 & 池旦正己 & 東 \\
\hline
\end{tabular}

\section{STUDY ON DECOMPOSITION GAS FOR DIAGNOSTICS OF GAS-INSULATED TRANSFORMERS}

Shigemitsu Okabe, Member, Takahiro Ohno, Member (Tokyo Electric Power Co.,Inc)

Tsuneo Kobayashi, Member, Kenji Kawaguchi, Member, Yasuaki ishioka, Member, Tamotsu Inoue, Member, Toshiyuki Saida, Member, Masami Ikeda, Member (Toshiba Corpration)

\begin{abstract}
Concentration in population and business activities results in high energy demand in urban areas. This requires the construction of underground substations. Oil-less, non-flammable and non-explosive equipment is recommended for underground substations . Therefore, gas-insulated transformers have been developed. Development of the method for diagnosis of gas-insulated transformers is required.

In this paper experimental survey over the main components of decomposes generated by various faults in gas-insulated transformers is described that is carried out through simplified model tests. The phenomena of overheat and partial discharge are modeled, taking the actual materials related to each fault into account. For example , $\mathrm{CO}, \mathrm{CO}_{2}$, and aldehydes are produced by an overheat from pressboards and PET-films. The amount of gas production increases with temperature rise. While various types of gases are produced from the partial discharge, principal components are $\mathrm{SO}_{2}$ and $\mathrm{SOF}_{2}$. These results will be used to develop the diagnostics method for gas-insulated transformers.
\end{abstract}

キーワード：ガス絶縁変圧器、異常診断、ガス分析、過熱、部分放電、S F 6 ガス、プレスボード、PETフィルム

\section{1.はじめに}

近年、大都市の電力需要の集中が進んでいる。しかし用 地難や防災上の理由から、都市部に変電所を建設すること は年々困難になってきている。そのため、大容量の地下変 電所の需要が急激に高まってきている。ガス絶縁変圧器は 配電用を主体に伸び、人口が密集するビルや地下へ数多く 配置されてきた。最近は大容量のガス絶縁変压器の開発も 進み(1)、配電のみでなく大容量変電所でも適用され始め ている。

ガス絶縁変王器では、主たる絶縁材料として油入変王器 に伝統的に使われてきた絶縁紙に替わって、巻線絶縁には ポリエチレンテレフタレートフィルム（PETフィルム） が使用される。そのため、変圧器内部で異常が発生した場 合には、使用している材料が油入変圧器と異なるため、発 生する分解ガスも異なることが考えられるが、これについ て調査した報告例はまだ少ない(2)(3（4)。特に、ガス絶 縁変圧器の異常診断を考える上て、変圧器が正常に運転さ れている領域で発生する分解ガスの調查は、変死器の運転 が正常か異常かを判断するためには不可欠であるが、これ まではこの頱域まで踏み込んだ報告はなされておらず、多 様な現象を検知、判断するためにはさらなるデー夕の集積 が必要とされている(ら)。
本諭文では、正常運転領域から異常運転領域まで、幅広 いエネルギー範囲において変圧器内部に発生する分解ガス を調查した。また、その結果をむとに、得られたデータが どのように異常診断に利用できるかを考察した。

\section{2. 調查項目}

変圧器内部の異常としては、大きく過熱翼常と放電異常 に分類される。変圧器の構造・材料などを模擬したモテル により、変圧器内部で過熱異常、及び放電唭常が起きた場 合に発生する分解ガスについて調查した。

\section{<2・1> 加熱試倹}

加熱試験では、2つの運転状態を模擬して発生する分解 ガスの調查を行った。すなわち、変圧器内部に異常が発生 し、絶縁材料や金属面に塗布される塗料が高温にさらされ た場合に発生する分解ガスについては、短時間加熱試験に より調查した。

また、正常運転状態において、軽微な異常や過負荷など、 絶縁物が運転温度に近い比較的低温領域で長時間加熱され た場合に発生する分解ガスについては、長時間加熱試験に より調查した。 


\section{$\langle 2 \cdot 2\rangle$ 部分放電試联}

変圧器内部に絶縁不良や異常電圧の侵入等により絶縁異 常が発生した場合、䋓縁物の沿面やS F。ガス中に部分放 電を生じる。部分放電試験では、変压器内部の部分放電発 生を模擬したモテルによって、絶縁物を介在した場合と、 絶緑物を介在しないS F 6 ガス単体の場合について、部分 放電が生じた際に発生する分解ガスをそれぞれ調查した。

絶縁物を介さないS F 6 ガス単体での部分放電試験につ いては、変压器内部には被覆されていない高電压導体は基 本的にはないが、放電エネルギーによって S F 。ガスから どのような分解ガスが発生するかの調查を行う必要がある と考え、実施した。

\section{3. 加熱試鉂}

逗熱異常によって、絶縁材料から発生する特街的な分解 ガスを把握するための高温短時間加熱試験と、正常運転状 態における軽微な異常時に発生する分解ガスを把握するた めの但温長時間加熱試験の 2 通りの加熱試験を行った。

\section{〈3*1>高温短時間加熱試䮊}

高温短時間加熱試驗では、遇熱により絶縁材料から発生 する分解ガスと、金属材料共存における S F。ガスの分解 ガスを調查するため、試料として絶縁材料と金属材料を加 熱した。

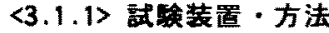

(1) 絶縁材料

図 1 に高温短時間加熱試験の試験装置を示す。試料はガ 又絶縁変王器の卷線の主要絶縁材料である耐熱ポリエチレ ンテレフタレート（PET）フィルム、プレスボード、お よび変圧器内部の金属面に笁布されるエポキシ塗料を3mm 角（1〜20g）にしたものを準備した。なお、耐熱P E Tフ ィルムは、PETフィルムに対して低分子不純物含有量を 减少させ耐熱性を改良した耐熱クラスBの絶縁材料である。 試料は $105^{\circ} \mathrm{C} 3$ 時間乾燥後、ガラス管内に陚料を設置し、 バルブ $\mathrm{A} 、 \mathrm{C}$ を開放して $\mathrm{A}$ 部から徐々に $\mathrm{N}_{2}$ ガスを $\mathrm{A} \rightarrow \mathrm{B}$ $\rightarrow \mathrm{C} \rightarrow \mathrm{D}$ に流した後、管の両端のバルブ $\mathrm{A} 、 \mathrm{C}$ を閉鎖する。 次に、恒温槽の温度を上げて加熱し、陚料温度が所定の 温度に達してから30分〜 4 時閣保持した後に A、Cを開故 してA部から $\mathrm{N}_{2}$ ガスを導入して、発生する分解ガスを捕 集した。なお $\mathrm{N}_{2}$ ガス中で加熱試験を実施したのは、 $300^{\circ} \mathrm{C}$

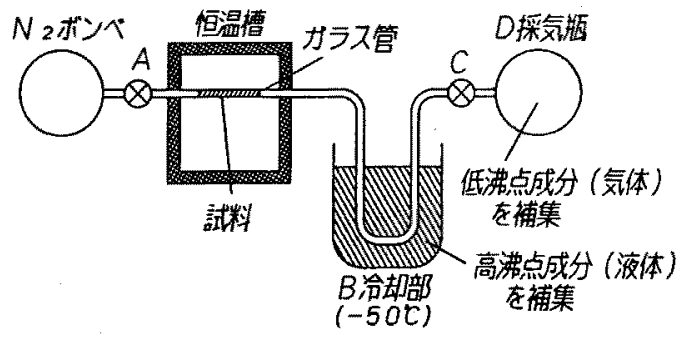

図 1 熱分解装置

Fig.1. Thermal Decomposition Test Setup
までの加熱条件下で、SF。ガスが熱分解し、ガラス管を 損傷してしまうのを避けるためである。

分解ガスのうち高沸点成分についてはB 部 (冷却部) に 液体として、また低沸点成分についてはD部（採気瓶）に それそれ捕集した。これらの捕集した分解ガスをガスクロ マトグラフ（GＣ）、及びガスクロマトグラフノ顊量分析 計（GC/M S）により分析した。なお、加熱温度は耐熱 PETフィルムの融点 $\left(260^{\circ} \mathrm{C}\right)$ 近くの温度として、180 〜300年の笘囲でそれそれれ加熱した。表1に加熱条件を示 す。

表 1 各種絶縁材料の加熱条件

Table.1 Heal Condition of Insulation Materials

\begin{tabular}{|c|c|c|c|c|c|c|}
\hline 絶 縁 & 加熱温度 & $180^{\circ} \mathrm{C}$ & $200^{\circ} \mathrm{C}$ & $220^{\circ} \mathrm{C}$ & $250^{\circ} \mathrm{C}$ & $300^{\circ} \mathrm{C}$ \\
\hline 材 料 & 加熱時間 & $4 \mathrm{~h}$ & $4 h$ & $4 h$ & $4 \mathrm{~h}$ & 30min \\
\hline \multicolumn{2}{|c|}{ 㽢熱PET7ィ仙＊ } & 0 & 0 & - & 0 & 0 \\
\hline \multicolumn{2}{|c|}{ プレスボード* } & 0 & 0 & - & 0 & 0 \\
\hline \multicolumn{2}{|c|}{ エポキシ塗料* } & - & 0 & 0 & 0 & - \\
\hline \multicolumn{2}{|c|}{ 金属材料＃ } & 0 & 0 & 0 & 0 & - \\
\hline
\end{tabular}

O : 測定実施

一：測定省略

*： $\mathrm{N}_{2}$ 中で加熱

\#：S F 8 中で加熱

（2）金属材料

珪素鍮板 (246g)と銅板(173g)の表面を溶媒で洗浄し、図 2 に示すステンレス製試騃容器に各々個別に入机て封じた 後、10Pa以下の减圧下で 3 時間真空引をを行う。その後、 $S F_{6}{ }_{6}$ ガスを0.2MPa（絶対圧力）充填し、1 $180^{\circ} \mathrm{C} \sim 300^{\circ} \mathrm{C}$ て それぞれ30分〜4時間加熱した。表1に加熱条件を示す。

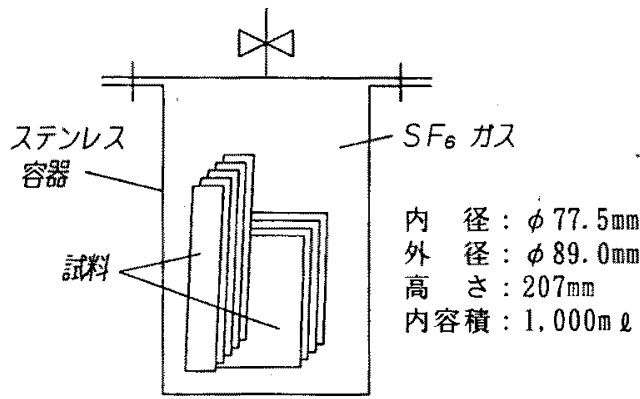

図 2 試験容器

Fig.2. Test Vessel Container

\section{$<3.1 .2>$ 結果}

\section{(1) 絶縁材料}

表 2 に各絶縁材料から発生する分解ガスの分析結果を示 す。䩂熱P E Tフィルムからの分解ガスは $200^{\circ} \mathrm{C}$ 以下は、

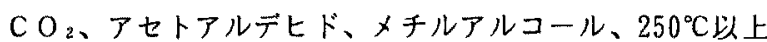
ではらにメタンなども検出された。 
一方、プレスボードからの分解ガスは、耐熱性が耐熱P E Tフィルムよりも低いために、発生量や種類も多く、耐 熱PETフィルムから発生する成分以外に、他のアルデ ド類、ケトン類、フラン類およびフルフラールとその誘導 体など20種類以上の分解ガスが検出された。

エポキシ塗料からの分解ガスは、 $220^{\circ} \mathrm{C}$ 以下でC O 成分として、少量の水素、C $\mathrm{O} 、 \mathrm{C}_{1-3}$ 炭化水素類、アセ トアルデヒド、メチルアルコール、250C Cでさらにメチル ピラジンなどが検出された。

各絶縁材料から発生した共通の主要分解ガスは、C O 2 アセトアルデヒド、およびメチルアルコールなどであり、 その生成量は、プレスボードが耐熱P E Tフィルムの数倍 〜数十倍多かった。

プレスボードから発生する、メチルエチルケトン、メチ ルイソブチルケトン、酷酸メチルおよびフルフラール類は、 耐熱P E Tフィルムから発生しないため、プレスボードの 特徴成分といえる。特にフルフラールは油入変圧器の劣化
䛦断の指標として内外で検討されている成分である ${ }^{(6)} 。$ フルフラールは高沸点 $\left(164^{\circ} \mathrm{C}\right)$ のため液体として䋓縁 油中に含まれており、抽出して液体クロマトグラフにより 分析されるが、本実験では、S F。ガス中においても険出 できており、注目すべき成分のひとつとして考えられる。

また、エポキシ塗料特有の発生分解ガスはメチルピラジ ンである。

\section{（2）金属材料}

表 3 に、金属材料によるS F。の分解ガスの測定結果を 示す。金属材料によるS F 6 の分解ガスは、 $180^{\circ} \mathrm{C}$ 以上で微 量のS $\mathrm{O}_{2}$ が検出されたが、これまでの研究例 (7)で報告さ れている、金属材料との共存におりる $\mathrm{SO}_{2} \mathrm{~F}_{2} 、 \mathrm{HF}$ 生 成は検出されなかった。珪素銅板と銅におりるS $\mathrm{S}_{2}$ 発生 量は、瑟素鎦板が銅よりも多かったが、珪素鋼板と銅を共 存させた系においては単独よりも特に多くなるような結果 は得られなかった。

表 2 絶縁材料の分解ガス

Table. 2 Decomposition Gas of Insulating Materials

\begin{tabular}{|c|c|c|c|c|c|c|c|c|c|c|c|c|}
\hline \multirow{3}{*}{ 分析対象分解ガス } & \multirow{2}{*}{\begin{tabular}{|c|} 
試 料 \\
加熱温度 \\
\end{tabular}} & \multicolumn{4}{|c|}{ 耐熱PETフィルム } & \multicolumn{4}{|c|}{ プレスボード } & \multicolumn{3}{|c|}{ エポキシ塗料 } \\
\hline & & $180^{\circ} \mathrm{C}$ & $200^{\circ} \mathrm{C}$ & $250^{\circ} \mathrm{C}$ & $300^{\circ} \mathrm{C}$ & $180^{\circ} \mathrm{C}$ & $200^{\circ} \mathrm{C}$ & $250^{\circ} \mathrm{C}$ & $300^{\circ} \mathrm{C}$ & $200^{\circ} \mathrm{C}$ & $220^{\circ} \mathrm{C}$ & $250^{\circ} \mathrm{C}$ \\
\hline & 加熱時間 & $4 \mathrm{~h}$ & $4 h$ & $4 h$ & 30min & $4 \mathrm{~h}$ & $4 \mathrm{~h}$ & $4 h$ & $30 \mathrm{~min}$ & $4 h$ & $4 h$ & $4 h$ \\
\hline \multicolumn{2}{|l|}{ 水素 $\left(\mathrm{H}_{2}\right)$} & $x$ & $x$ & $x$ & $x$ & $x$ & $x$ & $x$ & 0 & 0 & 0 & (9) \\
\hline \multicolumn{2}{|l|}{ 一酸化炭素 (CO) } & $x$ & $x$ & $x$ & $x$ & 0 & (O) & (C) & (O) & 0 & 0 & 0 \\
\hline \multicolumn{2}{|l|}{ 二酸化炭素 $\left(\mathrm{CO}_{2}\right)$} & 0 & 0 & 0 & 0 & (C) & (O) & (C) & (0) & (O) & (O) & (O) \\
\hline \multicolumn{2}{|l|}{ メタン $\left(\mathrm{CH}_{4}\right)$} & $x$ & $x$ & $\triangle$ & $\triangle$ & $\triangle$ & $\triangle$ & 0 & 0 & $\triangle$ & $\triangle$ & 0 \\
\hline \multicolumn{2}{|l|}{ エチレン $\left(\mathrm{C}_{2} \mathrm{H}_{4}\right)$} & $x$ & $x$ & $x$ & $x$ & $x$ & $x$ & $\triangle$ & $\Delta$ & $x$ & $x$ & $\triangle$ \\
\hline \multicolumn{2}{|l|}{ エタン $\left(\mathrm{C}_{2} \mathrm{H}_{6}\right)$} & $x$ & $x$ & $x$ & $x$ & $x$ & $x$ & $\triangle$ & $\triangle$ & $x$ & $\triangle$ & $\triangle$ \\
\hline \multicolumn{2}{|c|}{ アセトアルデヒド $\left(\mathrm{C}_{2} \mathrm{H}_{4} 0\right) *$} & $x$ & $\triangle$ & 0 & 0 & $\triangle$ & $\triangle$ & 0 & (O) & 0 & 0 & 0 \\
\hline \multicolumn{2}{|c|}{ メチルアルコール $\left(\mathrm{CH}_{3} \mathrm{OH}\right)$} & $\triangle$ & $\triangle$ & 0 & $x$ & 0 & 0 & 0 & $x$ & $\triangle$ & $\triangle$ & 0 \\
\hline \multicolumn{2}{|l|}{ アセトン $\left(\mathrm{C}_{3} \mathrm{H}_{6} \mathrm{O}\right)$} & $x$ & $x$ & $x$ & $x$ & $x$ & $x$ & 0 & $x$ & $x$ & $x$ & $\triangle$ \\
\hline \multicolumn{2}{|c|}{ メチルエチルケトン $\left(\mathrm{C}_{4} \mathrm{H}_{8} \mathrm{O}\right)$} & $x$ & $x$ & $x$ & $x$ & $x$ & $x$ & 0 & $\triangle$ & $\dot{x}$ & $x$ & $\times$ \\
\hline \multicolumn{2}{|c|}{ メチルイソブチルケトン } & $x$ & $x$ & $x$ & $x$ & $x$ & $x$ & $x$ & $\triangle$ & $x$ & $x$ & $x$ \\
\hline \multicolumn{2}{|c|}{ フルフラール $\left(\mathrm{C}_{5} \mathrm{H}_{4} \mathrm{O}_{2}\right)$} & $x$ & - & - & $x$ & $x$ & 0 & 0 & (O) & $x$ & $x$ & $x$ \\
\hline \multicolumn{2}{|c|}{ メチルフラン $\left(\mathrm{C}_{5} \mathrm{H}_{6} 0\right)$} & $x$ & - & - & $x$ & $x$ & - & - & 0 & $x$ & $x$ & $x$ \\
\hline \multicolumn{2}{|c|}{ メチルフルフラール $\left(\mathrm{C}_{6} \mathrm{H}_{6} \mathrm{O}_{2}\right)$} & $x$ & - & - & $x$ & $x$ & - & - & (a) & $x$ & $x$ & $x$ \\
\hline \multicolumn{2}{|c|}{$\begin{array}{l}\text { ヒドロキシメチル }\left(\mathrm{C}_{6} \mathrm{H}_{6} \mathrm{O}_{3}\right) \\
\text { フルフラール }\end{array}$} & $x$ & - & - & $x$ & $x$ & - & - & 0 & $x$ & $x$ & $x$ \\
\hline \multicolumn{2}{|l|}{ 酿酸メチル $\left(\mathrm{C}_{3} \mathrm{H}_{6} \mathrm{O}_{2}\right)$} & $x$ & - & - & $x$ & $x$ & - & - & () & $x$ & $x$ & $x$ \\
\hline \multicolumn{2}{|c|}{ メチルピラジン $\left(\mathrm{C}_{5} \mathrm{H}_{6} \mathrm{O}_{2}\right)$} & $x$ & - & - & $x$ & $x$ & - & - & $x$ & $x$ & $x$ & $\Delta$ \\
\hline
\end{tabular}

・ $\mathrm{N}_{2}$ ガス中で測定 *：険知管で測定したもの

・分解ガスの表示基準 $=@$ は $0.1 \mathrm{~m} 1 / \mathrm{g}$ 以上、○は0.01 0. $1 \mathrm{ml} / \mathrm{g}$ 未満、

$\triangle$ は0.001 0.01m1/g末満、×は $0.001 \mathrm{ml} / \mathrm{g}$ 末満 
表 3 金属材料の分解ガス（珪素鋼板十錩）

Table. 3 Decomposition Gas of Metal Materials

\begin{tabular}{|c|c|c|c|c|c|}
\hline \multirow{2}{*}{ 分析対象分解ガス } & 加熱温度 & $180^{\circ} \mathrm{C}$ & $200^{\circ} \mathrm{C}$ & $220^{\circ} \mathrm{C}$ & $250^{\circ} \mathrm{C}$ \\
\hline & 加熱時間 & $4 h$ & $4 h$ & $4 \mathrm{~h}$ & $4 \mathrm{~h}$ \\
\hline \multicolumn{2}{|c|}{ 弗化スリフリル $\left(\mathrm{SO}_{2} \mathrm{~F}_{2}\right)$} & $x$ & $x$ & $x$ & $\times$ \\
\hline \multicolumn{2}{|c|}{ 弗化チオニル $\left(\mathrm{SOF}_{2}\right)$} & $x$ & $x$ & $x$ & st \\
\hline \multicolumn{2}{|c|}{ 二酸化硫黄 $\left(\mathrm{SO}_{2}\right) *$} & is & 众 & $\hat{s}$ & $\hat{\imath}$ \\
\hline \multicolumn{2}{|l|}{ 弗化水素 $(\mathrm{HF}) *$} & $x$ & $x$ & $x$ & $x$ \\
\hline \multicolumn{2}{|l|}{ 四弗化炭素 $\left(\mathrm{CF}_{4}\right)$} & $x$ & $x$ & $x$ & $x$ \\
\hline
\end{tabular}

*: 検知管で測定したもの

$S F_{6}$ ガス中 $(0.2 \mathrm{MPa}$ : 絶対圧力) にて湖定 分解ガスの表示基準 $=x: 0.001 \mathrm{ml} / \mathrm{g}$ 末渵

$$
\text { 疼痕跡 }
$$

\section{〈3.2〉低温長時間加熱試駼}

\section{$\langle 3 \cdot 2 \cdot 1\rangle$ 試糇装置・方法}

厚さ50 $\mu$ mの耐熱P E Tフィルム、および厚さ2mmのプレ スボード約 $1 \sim 20 \mathrm{~g}$ を乾燥器中で $100^{\circ} \mathrm{C} 、 4$ 時間で乾燥した。 その後、それぞれ図 2 に示すステンレス製容器に各々個別 に入れ、0.1torr以下の真空引き後、S F。ガスを $0.2 \mathrm{MPa}$ (絶対圧力) で充填して密開し、乾燥器中で長時間の加熱

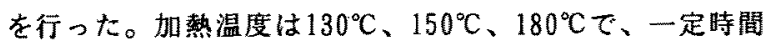
経通後絶縁材料から発生した分解ガスを分析した。各種絶 縁材料の加熱条件を表 4 に示す。なお、加熱温度は的熱 $\mathrm{P}$ $\mathrm{ET}$ Tィルムの酎熱クラス Bの許容最高温度 $130^{\circ} \mathrm{C}$ から設 定した。また、高温短時間加熱試験との連続性から $180^{\circ} \mathrm{C}$ まで設定した。

S F。ガスの分解ガスと絶縁材料から発生する分解ガス については、高温短時間加熱陚験の結果から得られた成分 の中から選定したガスについて、ガスクロマトグラフと検 知管により分析した。表 5 に分析対象分解ガスを示す。

\section{表 4 各種絶緑材料の加熱条件}

Table.4 Heat Condition of Insulation Materials

\begin{tabular}{|c|c|c|c|c|c|c|c|c|c|c|}
\hline \multirow{2}{*}{ 絶縁物 } & \multicolumn{3}{|c|}{$130^{\circ} \mathrm{C}$} & \multicolumn{3}{|c|}{$150^{\circ} \mathrm{C}$} & \multicolumn{4}{|c|}{$180^{\circ} \mathrm{C}$} \\
\hline & 2选想 & $2 ケ$ & 6 个月 & 2㹂間 & $2 \uparrow 月$ & $6 r 月$ & $2 \theta$ & 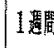 & $1+R$ & 3 个月 \\
\hline $\begin{array}{c}\text { 酎熱PET } \\
71 \text { Wh }\end{array}$ & 0 & 0 & 0 & 0 & 0 & 0 & - & 10 & 10 & 0 \\
\hline $7^{\circ} \vee x^{*}-H^{*}$ & 0 & 0 & 0 & 0 & 0 & 0 & 0 & 0 & 0 & - \\
\hline
\end{tabular}

すべて S F 6 中（0.2MPa：絶対压力）で加熱
$\mathrm{O}$ : 測定実施
一：測定省略

表 5 分析対象分解ガス

Table.5 Chemical Analyzed Gases

\begin{tabular}{|c|c|}
\hline 分析機器 & 分析対称分解ガス \\
\hline $\begin{array}{l}\text { ガスクロマト } \\
\text { グラフ }\end{array}$ & $\begin{array}{l}\mathrm{CO} O \mathrm{CO}, \mathrm{Cl}-40 \text { 炭化水素、 } \\
\text { アセトアルデヒド、メチルアルコール } \\
\text { メチルエチルケトン、 } \\
\text { メチルイソブチルケトン、アセトン、 } \\
\text { フルフラール }\end{array}$ \\
\hline 検知管 & $\mathrm{SO}_{2}$ (アセトアルデヒド) \\
\hline
\end{tabular}

\section{$\langle 3 \cdot 2 \cdot 2\rangle$ 結果}

表 6 に、低温長時間加熱試験でのガスクロマトグラフお よび検知管による分解ガスの分析結果を示す。また、図 3 $\mathrm{a}-\mathrm{c}$ に各絶縁材料からの分解ガスのうち、代表的成分で ある、 $\mathrm{CO}_{2}$ とアセトアルデヒドの発生ガス量の経時変化 を加熱温度別に示す。

耐熱P E Tフィルムの分解ガスは、 $150^{\circ} \mathrm{C}$ 以下で少量の

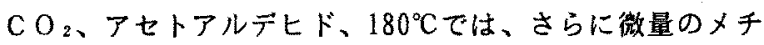
ルアルコールとメタン、COが検出された。プレスボード の分解ガスは、䡃熱PETフィルムで発生する成分以外に、 フルフラールとメチルエチルケトン、アセトン、アセチレ ンが検出された。分解ガスのうち共通に発生する分解ガス 量を比較すると、 $\mathrm{CO}_{2}$ 発生量は各温度でプレスボードの 方が耐熱P E Tフィルムより数十〜百倍程度多い。

なお、本試験で $130^{\circ} \mathrm{C}$ の条件でも $\mathrm{S} \mathrm{O}_{2}$ が微量ながら検出 された。絶縁物を容器中に入れず、SF。のみで加熱した ブランク試験でも検出されたため、SF。ガスがステンレ ス容器と反応して分解したものと考えられる。

表 6 絶縁材料の分解ガス

Table.6 Thermal Decomposition Substance of Insulating Materials

\begin{tabular}{|c|c|c|c|c|c|c|c|}
\hline 分 析 & 試 料 & \multicolumn{3}{|c|}{ 耐熱PET>1 } & \multicolumn{3}{|c|}{ プレスボード } \\
\hline 対 象 & 加熱温度 & $130 \%$ & $150^{\circ} \mathrm{C}$ & $180^{\circ} \mathrm{C}$ & $130^{\circ} \mathrm{C}$ & $150^{\circ} \mathrm{C}$ & $180^{\circ} \mathrm{C}$ \\
\hline ガ ス & 加熱時間 & $6 r$ 月 & 6 \%月 & 3ヶ月 & 6 万月 & 6 \%月 & 1 开 \\
\hline \multicolumn{2}{|c|}{ 一酸化炭素 } & $x$ & $x$ & (0) & (0) & (0) & (1) \\
\hline \multicolumn{2}{|c|}{ 二酸化炭素 } & 0 & 0 & (0) & (C) & (0) & (2) \\
\hline \multicolumn{2}{|l|}{ メタン } & $x$ & $x$ & $\triangle$ & $x$ & $x$ & $\triangle$ \\
\hline \multicolumn{2}{|c|}{ アセチレン } & $x$ & $x$ & $\triangle$ & $x$ & $x$ & $x$ \\
\hline \multicolumn{2}{|l|}{ エチレン } & $x$ & $x$ & $x$ & $x$ & $x$ & $x$ \\
\hline \multicolumn{2}{|l|}{ エタン } & $x$ & $x$ & $x$ & $x$ & $x$ & $x$ \\
\hline \multicolumn{2}{|c|}{ アセトアルデヒド* } & $\triangle$ & $\triangle$ & $\triangle$ & $x$ & 0 & (0) \\
\hline \multicolumn{2}{|c|}{ メチルアルコール } & - & - & $\triangle$ & - & - & (9) \\
\hline \multicolumn{2}{|l|}{ アセトン } & - & - & $x$ & - & - & (a) \\
\hline \multicolumn{2}{|c|}{ メチルエチルケトン } & - & - & $x$ & - & - & (Q) \\
\hline \multicolumn{2}{|c|}{ フルフラール } & - & - & - & - & - & (C) \\
\hline
\end{tabular}

*: 検知管で測定したもの

分解ガスの表示基準 $=$ ○は $0.1 \mathrm{ml} / \mathrm{g}$ 以上

○は0.01〜0.1ml/g末渵 $\triangle$ は $0.001 \sim 0.01 \mathrm{ml} / \mathrm{g}$ 末満 $\times$ は $0.001 \mathrm{ml} / \mathrm{g}$ 末満 


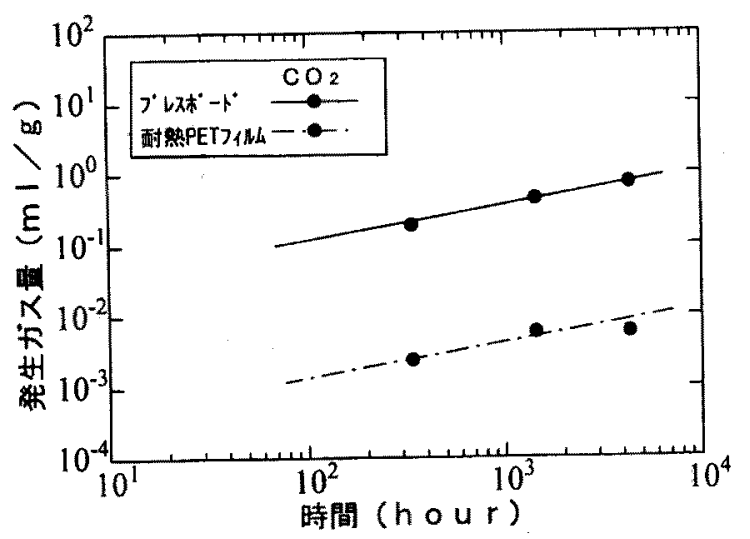

図3a $1300^{\circ} \mathrm{C}$ における分解ガス発生量の比較

Fig.3a.Diferrence of amount of Decomposition Gas between insulating materials $\left(130^{\circ} \mathrm{C}\right)$

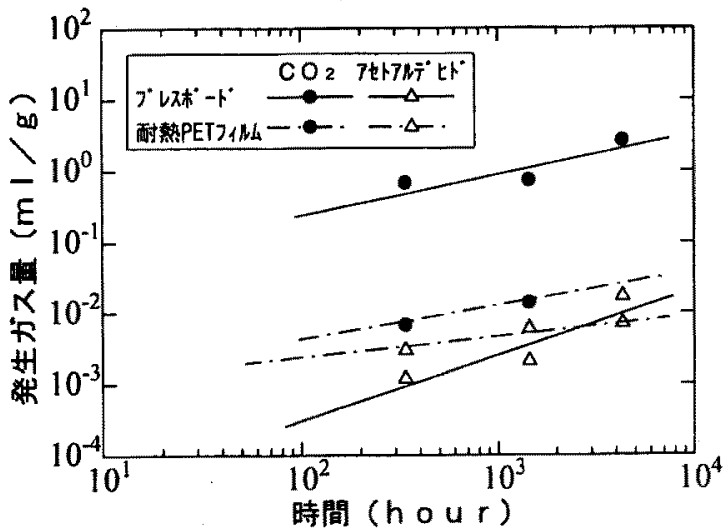

図 3 b $150{ }^{\circ} \mathrm{C}$ におりる分解ガス発生量の比較

Fig.3b.Diferrence of amount of Decomposition Gas between insulating materials $\left(150^{\circ} \mathrm{C}\right)$

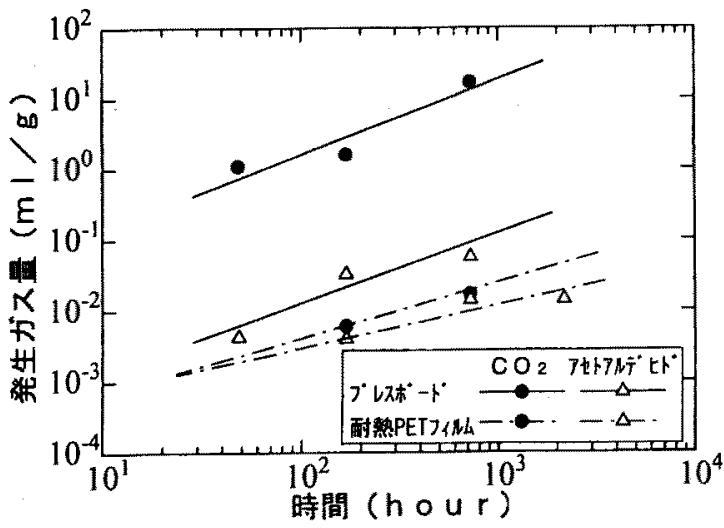

図 $3 \mathrm{c} \quad 180{ }^{\circ} \mathrm{C}$ における分解ガス発生量の比較

Fig.3c.Diferrence of amount of Decomposition Gas between insulating materials $\left(180^{\circ} \mathrm{C}\right)$

\section{4. 部分放電試験}

部分放電により発生する分解ガスの調查を、部分放電試 験モデルにより実施した。試験は絶縁物を介して部分放電 を発生させるモテルと、䋓縁物を介さない、ガス単体で部 分放電を発生させるモテルで行った。

\section{〈4・1〉試糇モデル}

（1）絶縁物を介した部分放電試験モデル

図 4 に針一平板モテルを示す。モテルは針〜平板電極橉 成で、電極間に絶縁物を挿入している。針電極（銅製：直 径 $0.9 \mathrm{~mm}$ ）は高王侧に配置し、先端曲率を約 $0.15 \mathrm{~mm} に て$ ある。平板電極は接地電極でステンレス製である。試料と

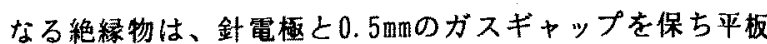
上に密着させて取り付けた。試料に用いた絶縁物は、ガス 絶縁変压器の巻線主要絶縁材料であるプレスボード（厚さ $4 \mathrm{~mm}) 、 \mathrm{PET}$ Tィルム（厚さ $0.05 \mathrm{~mm} \times 10$ 枚）である。

また、図 5 に示したPETフィルムで平角銅線（2.2m $\times 10 \mathrm{~mm}$ ）を絶縁被覆（被覆厚0. $5 \mathrm{~mm} ） し て$ 変王器の卷線桡 成を模擬した、ターン間モデルでも試験を実施した。

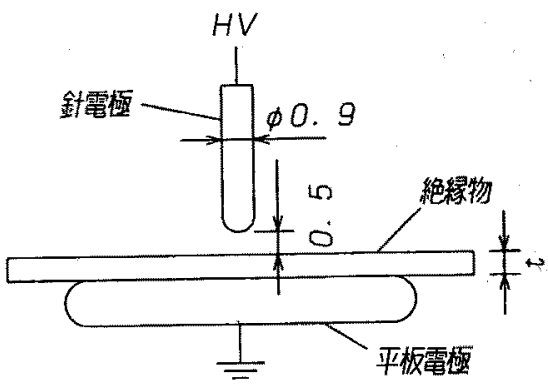

図 4 針一平板モデル

Fig.4. Needle-Plane Model

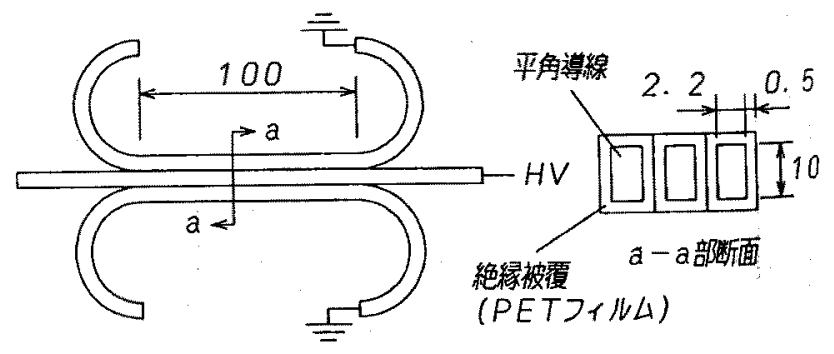

図 5 ターン間モデル

Fig.5.Turn-to-Turn Model

（2）絶緑物を介さない部分放電試験モデ

絶縁物を介さずにS F ${ }_{6} カ ゙ ス$ 単体で部分放電を発生させ るガスギャップモデルを図 5 に示す。モデルは針一平板電

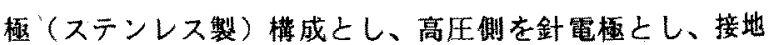
侧を平板電極とした。部分放電の発生頻度を高めるため、 針笔極を 4 本並列とし、4ヶ所のガスギャップで部分放電 を発生させる。ギャップ長は10〜15m比た。 


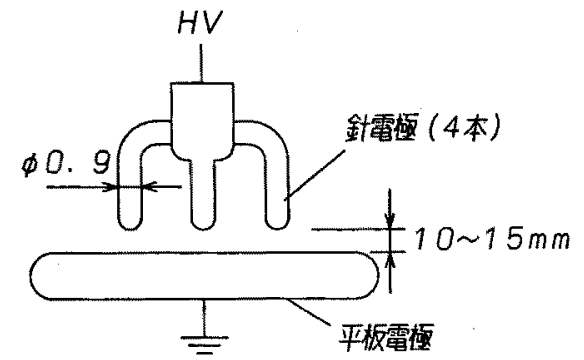

図 6 ガスギャップモデル

Fig.6.Gas-Gap Model

\section{〈4·2〉武医方法}

モテルは、 $90^{\circ} \mathrm{C} \times 72$ 時間熱風乾燥を実施後、図 7 に示す 試験装置の詿験用タンクにセットした。その後、10Pa以下 の王力で 4 時間真空引きし、S F 6 ガスを封入後、1 時間 静置し、交流電王 $(50 \mathrm{~Hz})$ を一定時間（1時間から約40時 間) 印加して針電極と平板電極間で部分故電 $(1000 \sim 10000$ $\mathrm{pC})$ 発生させた。その後、ガスクロマトグラフ及び検知 管によって、発生する分解ガスを分析した。

部分放電は、結合コンデンサに接続した部分放電測定器 による测定と、試料の接地線にスイッチングダイオードを 接続し、部分放電電流を整流して直流電流として測定する 方法の 2 㮔類の方法を用いて測定した。

放電エネルギーは、部分放電電流を積分して部分放電電 荷量を求め、部分放電電荷量と印加電压により算出した。 試銩は印加電圧、印加時間を変えて放電エネルギ一を変化 させて実施した。絶縁物を介したモテルについては、ガス 絶縁変王器の大容量器と中・小容量器とのS F 6 封入ガス 压の相違の影敕を調查するため、SF。ガス圧力を0.15MPa

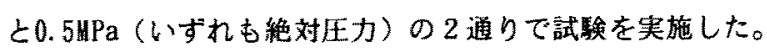
また、タンク容量の影響を調查するため、内容量 19 サトルと 75 リトNの 2 種類のタンクで武験を実施した。絶縁物を介さ ないガスギャップモデルにおいては、SF。ガス中の水分 による発生分解ガスの影牟を調查するため、S F。ガス中 にマイクロシリンジにより水分を封入し、水分量をを13 760vol ppmまで変化させた試験を実施した。なお、水分量 の設定は、ガス絶縁開閉装置の管理指針を目安に設定した。

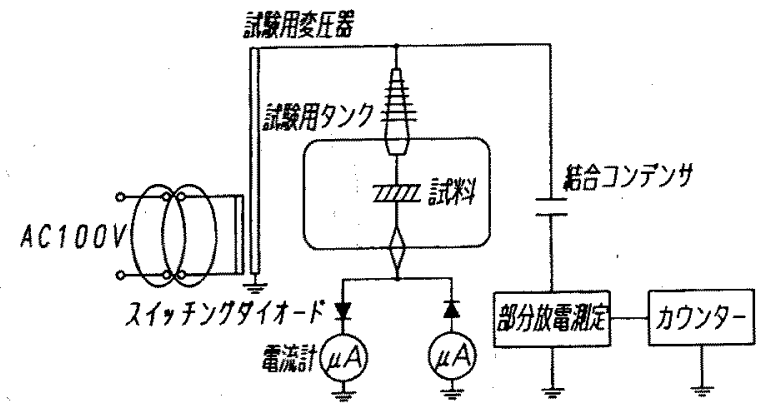

図 7 試験装置

Fig.7. Test Setup

\section{$\langle 4 \cdot 3\rangle$ 結果}

（1）絶緑物を介した放電放電試験モテル

プレスボードを介した針一平板モテルによるS F 6 ガス 分解ガスは、比較的故電エネルギーの低い領域で $\mathrm{S} \mathrm{O}_{2}$ の みが検出されたが、エネルギーがある程度 (1000J)大き くなると、SOaに加えてSOF 2 が検出された。さらにト レースながらC F4、C $\mathrm{CH}_{4}$ 等が検出された。これら $\mathrm{SO}_{2}$ 、 S OF 2、CF。の発生は、ガス死に関係せずに検出された。 $\mathrm{PET}$ Ｔィルムを介した針一平板モテルでも、 $\mathrm{SO}_{2} 、$ SOF 2 の発生はプレスボードと同様な特性を示していた が、C F ${ }_{4}$ の発生はみられなかった。また、PETフィル ムで被覆したターン間モテルについてむ、他のモデと同 様、S $\mathrm{SO}_{2} 、 \mathrm{SOF}_{2}$ が検出された。

図 8〜9にガス压を変化させた場合の、各モデルからの $\mathrm{SO}_{2} 、 \mathrm{SOF}_{2}$ の発生量を示す。発生量は、多少バラッキ のあるものの、放電エネルギーに对してほぼ同一曲線上て 表せられ、S F 5 ガス圧や、絶縁物の種類にあまり依存せ す、放笔エネルギーに比例する結果が得られた。

また、試験用タンクの容量を変化させ S F 6 ガス量の変 化が及汽す影響を険証した。各モデルでの結果をすべてプ ロットして図10に示す。これより、S F。ガス量の変化 に対する依存性は見られなかった。

（2）絶縁物を介さない部分放電試騃モデル

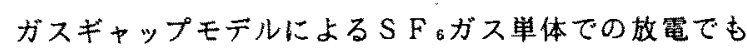
絶縁物を介した放䉓と同様、放電エネルギ一の低い領域で $\mathrm{S} \mathrm{O}_{2}$ が検出され、放電エネルギーの大きい領域で $\mathrm{S} \mathrm{O} \mathrm{O}_{2} に$

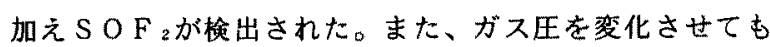
分解ガスの種類の差は見られなかった。図11にガス中水 分を変化させたときのガスギャップモデルでのS O 2 発生 量を示す。図より、S O 2 発生量は今回試験した領域での ガス中水分にはあまり影響されす、ほほ同じ特性で表され ることがわかる。

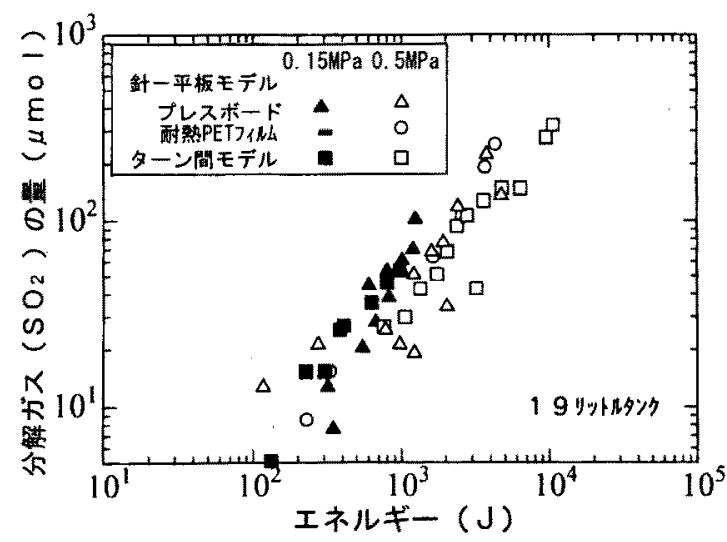

図 $8 \mathrm{SO}_{2}$ 発生量とエネルギーの関保（絶緣物放電） Fig.8. Relation Between amounts of decomposition $\mathrm{SO}_{2}$ and Partial-discharge energy 


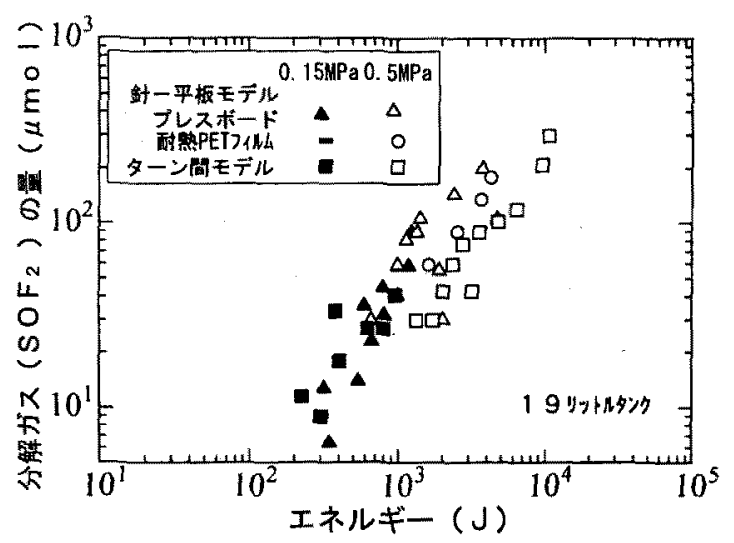

图 $9 \mathrm{SOF}_{2}$ 発生量とエネルギーの関係(䋓縁物放電)

Fig.9. Relation Between amounts of decomposition $\mathrm{SOF}_{2}$ and Partial-discharge energy

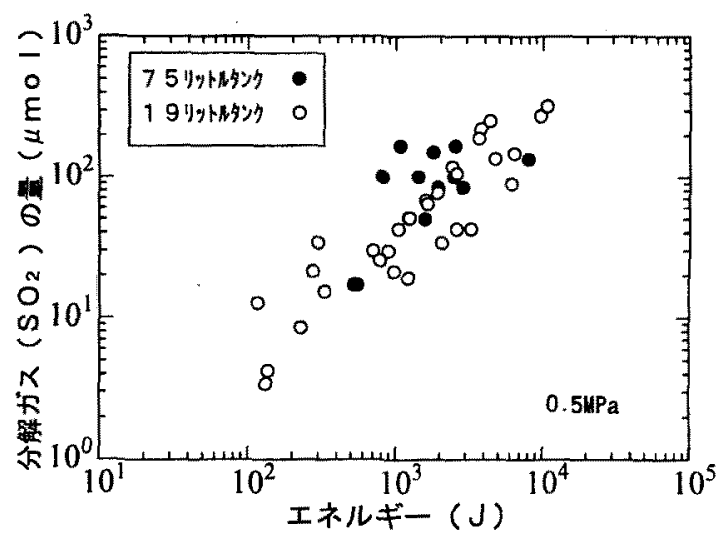

图 $10 \mathrm{SO}_{2}$ 発生量とエネルギ一の関係 (絶縁物放電)

Fig.10. Relation Between amounts of decomposition $\mathrm{SO}_{2}$ and Partial-discharge energy

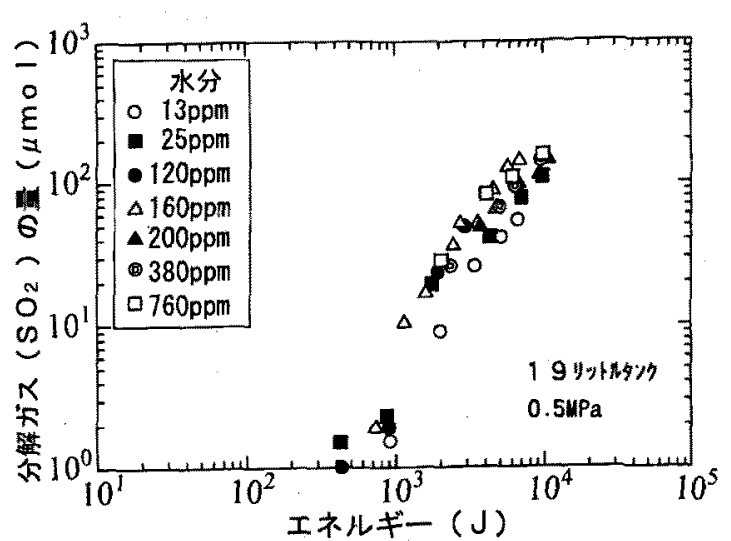

目11SO2発生量とエネルギ一の関係（ガス単体放電）

Fig.11. Relation Between amounts of decomposition $\mathrm{SO}_{2}$ and Partial-discharge energy

\section{5. 異常診断への考え方}

\section{く5・1〉異常に上り発生する分解ガス}

3 章、 4 章の結果を、翼常診断の観点で見直し以下に示 す。

今回の実験で各温度で絶縁材料の加熱により检出された 分解ガスを表 7 にまとめた。このほかに特徴として、量的 な面では温度上昇で発生量が多くなること、プレスボード からの発生量が多いことがある。

放電により発生する分解ガスの特徴としては、絶縁物を 介した放電の場合、S $\mathrm{F}_{6}$ ガス単体のガスに加え C F 4 が検 出されること、分解ガス発生量は故電エネルギ一に传存す ることが挙げられる。放電により検出された分解ガスを表 8 にまとめる。 $\mathrm{SF}_{8}$ ガス単体の放電では $\mathrm{SO}_{2} 、 \mathrm{SOF}_{2}$ が発生する。絶縁物が介在した場合では、まず絶緑物と電 極間のS F ${ }_{6}$ ガスが放電して、その後絶縁物部分の放電が 考えられる。

表 7 絶緣材料からの主要発生分解ガス

Table7. Main Decompostion Gases from Insulating Materials

\begin{tabular}{|c|c|c|c|}
\hline 加熱温度 & 耐熱P E Tフィルム & ブレスボード & エポキシ涂料 \\
\hline $130^{\circ} \mathrm{C}-150^{\circ} \mathrm{C}$ & $\mathrm{CO}_{2}$ & $\mathrm{CO}_{2}, \mathrm{CO}$ & - \\
\hline $150^{\circ} \mathrm{C}-180^{\circ} \mathrm{C}$ & $\mathrm{CO}^{2}$ 、アセトアルデヒド & $\mathrm{CO}_{2}, \mathrm{CO}$ & - \\
\hline $180^{\circ} \mathrm{C}-200^{\circ} \mathrm{C}$ & $\begin{array}{l}\mathrm{CO}_{2} \text { ○セトアルデヒド } \\
\text { メチルアルコール }\end{array}$ & $\begin{array}{l}\text { CO O } \mathrm{CO} \text { Oアセトアルデヒド } \\
\text { メルアルコール、フルフラール }\end{array}$ & - \\
\hline $200^{\circ} \mathrm{C}-250^{\circ} \mathrm{C}$ & $\begin{array}{l}\mathrm{CO}_{2} \text { ×セトアルデヒK゙ } \\
\text { メチルアルコール }\end{array}$ & $\begin{array}{l}C O O_{2} \text { ＯＯ、アセトアルデヒド } \\
\text { メチルアルコール、フルフラール }\end{array}$ & $\begin{array}{l}\text { COミ、CO、アセトアルデヒド } \\
\text { メチルアルコール }\end{array}$ \\
\hline $250^{\circ} \mathrm{C}-$ & 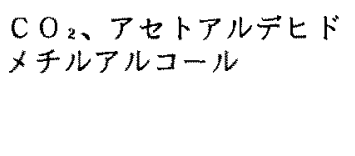 & $\begin{array}{l}\mathrm{CO}_{2} 、 \mathrm{CO} \text { 、アセトアルデヒド } \\
\text { メチルアルコール、フルフラール } \\
\text { 炭化水素、ケトン類、 } \\
\text { フラン化合物、酢酸メチル }\end{array}$ & $\begin{array}{l}\mathrm{CO} \mathrm{O}_{2} \mathrm{CO} \text { ○セトアルデヒド } \\
\text { ×チルアルコール、 } \\
\text { ×チルピラジン }\end{array}$ \\
\hline
\end{tabular}


表 8 部分放電による主要発生分解ガス

Table 8.Decomposition Gases at PD test

\begin{tabular}{|c|c|c|c|}
\hline \multicolumn{2}{|c|}{ 部分放電工视代 - } & 小 & 大 \\
\hline \multicolumn{2}{|c|}{ ガスギャップモデル } & $\mathrm{SO}_{2}$ & $\mathrm{SO}_{2} \mathrm{SOF}_{2}$ \\
\hline \multirow{2}{*}{$\begin{array}{r}\text { 針-平板電極 } \\
\text { +絶縁物 }\end{array}$} & プレスボード & $\mathrm{SO}_{2}$ & $\mathrm{SO}_{2} \mathrm{SOF}_{2} \mathrm{CF}_{4} \quad \mathrm{CH}_{4}$ \\
\hline & РET7ィルム & $\mathrm{SO}_{2} \mathrm{SOF}_{2}$ & $\mathrm{SO}_{2} \mathrm{SOF}_{2}$ \\
\hline \multicolumn{2}{|c|}{ ターン間モデル } & $\mathrm{SO}_{2} \mathrm{SOF}_{2}$ & $\mathrm{SO}_{2} \mathrm{SOF}_{2} \mathrm{CF}_{4}$ \\
\hline
\end{tabular}

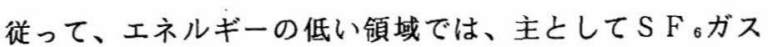
単体で、 $\mathrm{S} \mathrm{O}_{2} 、 \mathrm{SOF}_{2}$ が発生し、エネルギーが大きい領 域で絶縁物表面が破壊を始めると、炭素が発生し、S F 6 ガス単体で発生する分解ガスに加え C F 4 が発生するもの と考えられる。

これらのことから、異常診断への考え方を、次のように 示す。

\section{〈5.2〉異常診断法構策の考え方}

\section{$\langle 5 \cdot 2 \cdot 1>$ 正常建転}

正常運転においてお、過負荷運転などによる過熱により ガス発生があるので、変圧器内の温度分布から正常運転時 の分解ガス発生量を予測しておくか、実運転での分解ガス 発生量をデータベースとして作成しておく。今回の検討で 実運転温度に近い領域までのデータが得られたので、平常 運転時に発生する分解ガス量を推定することができる。

\section{$\langle 5 \cdot 2 \cdot 2\rangle$ 異常運転}

<5・2・1>での発生量より多量の分解ガスが発生すれば異 常と判断される。さらに、前述の通り絶縁材料および温度 による分解ガス発生の特徴と変圧器内部の設計情報から、 異常部位、温度などを推定できる。

部分放電の異常があったとき、有機物が関与しない場合 には S F ${ }_{6}$ の分解ガスである $\mathrm{SO}_{2} 、 \mathrm{SOF}_{2}$ が異常の指標 ガスとなり、さらに部分放電に有機物が関われば C F 4 が 加わる。

\section{6.むすび}

ガス絶縁変圧器の絶縁に主に使用される絶縁材料、金属 材料を S F 6 ガス中などで加熱し、また部分放電試験によ り、発生分解ガスを調へた。得られた結果の概要は次の通 りである。

（1）絶縁材料の過熱異常により $\mathrm{C} \mathrm{O}_{2} 、 \mathrm{CO}$ 、アセトア ルデヒド、メチルアルコールなどの分解ガスが発生し、主 成分は $\mathrm{CO}_{2}$ と $\mathrm{CO}$ である。

（2）プレスボードからの分解ガス発生量は耐熱P E T フ イルムからの発生量よりむ多く、 $250^{\circ} \mathrm{C} 、 300^{\circ} \mathrm{C}$ という高温 では、プレスボードから特徴的な多くの分解ガスが発生す る。
（3）加熱温度、材料の違いなどで分解ガス発生の様子に 特徵があり、異常診断の資料として役立てられる。

（4）部分放電により発生する S F 6 ガスの分解ガスは放 電エネルギーの小さい領域では $\mathrm{S} \mathrm{O}_{2}$ が主に検出され、エ ネルギーが大きくなると、さらに $\mathrm{SOF}{ }_{2}$ が検出される。

（5）絶縁物を介した放電では、S F 6 ガス単体放電で発 生する分解ガスに加えて C F 4 が痕跡程度検出され、その 発生量は、 $\mathrm{SO}_{2} \gg \mathrm{SOF}_{2}>\mathrm{CF}_{4}$ である。

（6）エネルギーに対する分解ガスの発生量は、ガス圧 力、絶縁物の種類にあまり依存せず、エネルギーにのみ依 存する。

今回の試験で、ガス絶縁変圧器内部に用いられる各部材 から、過熱異常や部分放電異常により発生する分解ガスの 種類や発生量について把握することができた。今後は得ら れたデータをむとに異常診断法を検討していきたい。

(平成 9 年 8 月 20 日受付)

$$
\text { 文献 }
$$

（1）高橋、田中、他：「大容量ガス絶縁変圧器の開発」、 電学論 B、115巻 4 号、平成 7 年

（2）電気学会技術報告：「不燃性・難燃性変压器の現状と その動向」、第 459 号、平成 5 年 4 月

（3）戸田、池田、石岡、毛受：「ガス絶縁変圧器の絶縁材 料の熱劣化特性」、電学論 B、115巻 4 号、平成 7 年

(4) 向山、工藤、他：「ガス絶縁変圧器の各種内部異常に よる主要な分解生成物」、電学誌 B、111巻、第 12 号、 平成 3 年

(5) 岡部、大野、他：「ガス絶縁変圧器要素モデルによる 分解生成物の検討」、平 8 電気学会全大、No. 591

（6）張替、後藤、太田、月岡：「フルフラールによる油入 変圧器の経年劣化診断の研究」、電学論 A、112、 pp589、平成 2 年 6 月

(7) 井関、小原：「フッ素系絶縁ガスの安定性」電気学会 誌7 P1134(1968)

(8) F.Y.Chu : "SF6 Decomposition in Gas Insulated Equipment",IEEE Trans. on EI.,Vol.EI-21,No.5, pp693(1986)

岡部 成光 (正員) 1958年 9 月18日生。1981年 3 月東 京大学工学部電気工業科卒業。1986年 3 月 同大学大学院博士課程修了。同年 4 月東京 電力 (株) 入社。主として、変電機器の診 断技術および絶縁協調の研究に従事。現在、 電力技術研究所絶縁・機器研究室。工学博 士。1993年電気学会論文賞授賞。 


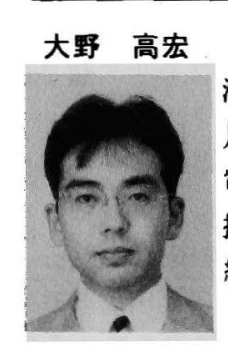

（正員）1964年10月 9 日生。1988年 3 月北 海道大学工学部電気工学科卒業。1990年 3 月同大大学院修士課程修了。同年 4 月東京 電力 (株) 人社。主として、変電機器診断 技術の研究に従事。現在、電力技術研究所 絶縁・機器研究室。

石岡 康昭 (正員) 1945年 3 月 9 日生。1963年 3 月秋

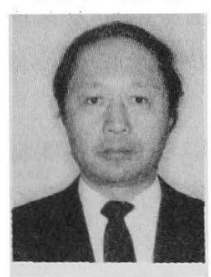
田県立能代工業高校化学科卒業。同年 4 月 （株）東芝入社。現在、重電技術研究所に 勤務。主として、変電機器用絶縁材料の研 究開発に従事。

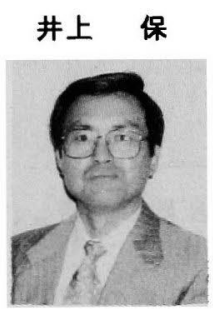

（正員）1949年 7 月 3 日生。1968年宮崎工 業高校電気科卒業。同年 4 月（株）東芝入 社。以来重電技術研究所において主として 油入変圧器及びガス絶縁変圧器絶縁の研究 に従事。

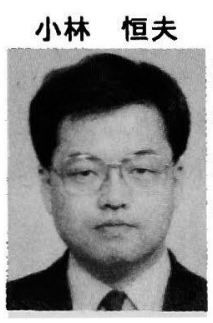

（正員）1959年 8 月 6 日生。1985年 3 月生。 慶應義塾大学大学院電気工学専攻修士課程 修了。同年 4 月（株）東芝入社。主として ガス絶縁変王器・ガス絶縁分路リアクトル の開発に従事。

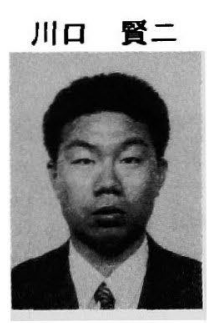

（正員）1970年 3 月28日生。1992年神奈川 大学電気工学科卒業。同年 4 月 (株) 東芝 入社。主として電力用変圧器、ガス絶縁変 圧器の開発に従事。

才田敏之（正員）1967年 1 月 12 日生。1991年 3 月名 古屋大学大学院電気工学専攻修士課程修了。
同年 4 月 (株) 東芝入社。同社電力変電技
術部において、主として変電プラントのシ
ステムエンジニアリングに従事。

池田 正己（正員）1943年 9 月14日生。1962年 3 月神 奈川県立神奈川工業高校電気科卒業。同年 (株) 東芝入社。同社重電技術研究所にお いて油入絶縁及び高電圧技術開発を担当。 82 年浜川崎工場変圧器部に転籍、電力用変 圧器の開発設計などの業務に従事。電気学 会論文賞、進歩賞、工学博士 (慶応大学)。 